\title{
STUDI PENGOLAHAN AIR BUANGAN DOMESTIK MENGGUNAKAN DIGESTER ANAEROBIK SATU TAHAP DAN DUA TAHAP
}

\section{STUDY OF DOMESTIC WASTEWATER TREATMENT USING ONE-STAGE AND TWO-STAGE ANAEROBIC DIGESTERS}

\author{
Tamaria Kesia Hutasoit, Halimatuddahliana, dan Amir Husin \\ Program Studi Teknik Lingkungan, Fakultas Teknik, Universitas Sumatera Utara, \\ Jl. Almamater, Kampus USU, Padang Bulan, Medan 20155, Indonesia \\ E-mail: tamariakesia@gmail.com
}

\begin{abstract}
Abstrak
Penelitian ini bertujuan untuk mempelajari pengaruh pengolahan anaerobik satu tahap dan dua tahap terhadap kinerja digester dalam pengolahan air buangan domestik dilihat dari segi laju degradasi substrat (COD), laju pertumbuhan mikroorganisme (VSS), laju produksi metabolit (VFA) dan laju produksi biogas. Tahapan penelitian ini meliputi proses aklimatisasi inokulum pada kondisi netral dan asam. Susbtrat yang digunakan adalah air buangan domestik. Kemudian ke dalam digester ditambahkan kotoran sapi sebagai inokulum. $\mathrm{pH}$ pada digester anaerobik satu tahap (R1) diatur pada $\mathrm{pH} 7$ yang dijalankan selama 40 hari dan $\mathrm{pH} 5.5$ pada digester anaerobik dua tahap:tahap pertama (R2-1) yang dijalankan selama 2 hari kemudian dilanjutkan dengan menambahkan inokulum dan diatur pada $\mathrm{pH} 7$ untuk selajutnya dijalankan sebagai digester anaerobik dua tahap:tahap kedua (R2-2) yang dijalankan selama 38 hari. Hasil menunjukkan yaitu efisiensi penyisihan konsentrasi COD pada R2 lebih tinggi dibandingkan R1. Konsentrasi VFA tertinggi dicapai pada R2-1: pada hari kedua.
\end{abstract}

Kata kunci: air buangan domestik, digester anaerobik dua tahap, digester anaerobik satu tahap, $\mathrm{pH}$.

\begin{abstract}
This research provides an analyzed performance of one and two-stage anaerobic digestion processes. One-stage and two-stage analyzed, individual, from substrate degradation, microbiological, metabolite and biogas production. First, the research initiated by acclimatization in a neutral condition and acid condition. Both one $(R 1)$ and two-stage $(R 2)$ digesters filled up with domestic wastewater. Into the digesters, it added cow dung as inoculums. $\mathrm{pH}$ in Rl maintained at $\mathrm{pH} 7$ for 40 days and $\mathrm{pH} 5.5$ in twostage anaerobic: first stage (R2-1) for two days. After that, the mixture added with inoculums and then adjusted at $\mathrm{pH} 7$ for the second stage (R2-2) for 38 days. The results showed that the substrate removal efficiency of two-phase is higher one-phase. The highest metabolite production obtained at R2-1: the $2^{\text {nd }}$ day.
\end{abstract}

Keywords: domestic wastewater, two-stage anaerobic digester, one-stage anaerobic digester, $\mathrm{pH}$.

\section{Pendahuluan}

Pada pengolahan anaerobik terdapat empat tahapan pada pengolahan anerobik yaitu hidrolisis, asidogenesis, asetogenesis dan metanogenesis. Secara umum keempat tahapan proses anaerobik tersebut dapat dipisahkan kedalam dua fasa (stage) yaitu fasa asidogenesis dan fasa metanogenesis. Pengolahan anaerobik secara dua tahap dapat dilakukan dengan mengatur $\mathrm{pH}$ yang sesuai untuk masing-masing tahapan proses anaerobik dimana bakteri metanogenik hanya dapat tumbuh pada rentang pH $(6.5$ - 8.5), tanpa oksigen dan kondisi suhu yang relatif stabil sedangkan bakteri hidrolitik dapat tumbuh pada rentang $\mathrm{pH}(4.7-6)$ dan pada kondisi lingkungan yang lebih beragam [14].

Penelitian ini berupaya untuk mempelajari pengaruh pengolahan anaerobik satu tahap dan dua tahap terhadap kinerja digester dalam pengolahan air buangan domestik dilihat dari segi laju degradasi substrat/ chemical oxygen demand (COD), laju pertumbuhan mikroorganisme/ volatile suspendeed solid (VSS) dan laju produksi metabolit/ volatile fatty acid (VFA) dan laju produksi biogas

Teori

Pengolahan anaerobik merupakan proses degradasi substansi organik oleh mikroorganisme pada keadaan tanpa oksigen [2].

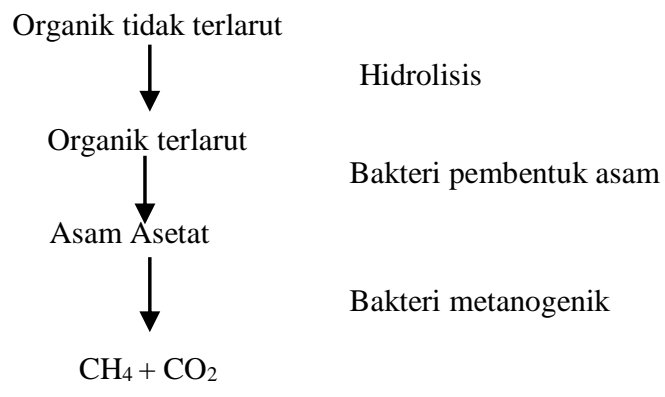

Gambar 1. Bagan Proses Pengolahan Anaerobik 
Proses perombakan yang terjadi pada digester anaerobik meliputi empat tahap perombakan yang dapat dilihat pada gambar yaitu hidrolisis, asidogenesis, asetogenesis dan metanogenesis.

a. Hidrolisis:

Hidrolisis merupakan tahap pemutusan rantai atau pemecahan molekul bahan organik kompleks (karbohidrat, protein dan lemak) sehingga terbentuk bahan organik yang lebih sederhana.

$\left(\mathrm{C}_{6} \mathrm{H}_{12} \mathrm{O}_{6}\right)_{n}+\mathrm{H}_{2} \mathrm{O} \rightarrow \mathrm{nC}_{6} \mathrm{H}_{12} \mathrm{O}$.

b. Asidogenesis:

Asidogenesis merupakan tahap perombakan bahan hasil proses hidrolisis menjadi senyawa-senyawa alkohol dan asamasam volatil seperti methanol, etanol, asam asetat, asam butirat, formiat, propionate dan lainlain.

$\mathrm{nC}_{6} \mathrm{H}_{12} \mathrm{O}_{6} \rightarrow 2 \mathrm{n}\left(\mathrm{CH}_{3} \mathrm{CH}_{2} \mathrm{COOH}\right)+2 \mathrm{nCO}_{2} \ldots \ldots$.

c. Asetogenesis:

Asetogenesis yaitu asam-asam volatil yang dihasilkan dari tahap asidogenesis diubah menjadi asam asetat dan $\mathrm{CO}_{2}$.

$\mathrm{CH}_{3} \mathrm{CH}_{2} \mathrm{COOH} \rightarrow \mathrm{CH}_{3} \mathrm{COOH}+\mathrm{CO}_{2}+3 \mathrm{H}_{2}$

d. Metanogenesis:

Metanogenesis merupakan tahap terakhir proses anaerobik dimana asam asetat dikonversi menjadi $\mathrm{CH}_{4}$ dan $\mathrm{CO}_{2}[10]$.

$\mathrm{CH}_{3} \mathrm{COOH} \rightarrow \mathrm{CH}_{4}+\mathrm{CO}_{2}$

Pengolahan anaerobik dua tahap yang dilakukan secara terpisah pertama kali disarankan oleh Pohland dan Ghosh. Tahapan umum dalam dekomposisi anaerobik terdiri dari dua tahapan utama yaitu acid production dan methane production. Tahapan pertama yaitu acid production yang merupakan reaksi hidrolisis bahan organik. Sedangkan tahapan kedua yaitu methane production yang merupakan proses pendegradasian produk tahapan pertama oleh bakteri methanogen menjadi metana dan dan karbondioksida [4].

Keuntungan pengolahan anaerobik dua tahap dibandingkan pengolahan anaerobik satu tahap adalah kondisi lingkungan di setiap tahap digester dapat dioptimalkan sehingga sesuai dengan kondisi pertumbuhan bakteri, volume reaktor yang dibutuhkan lebih kecil, lebih cepat dalam mendegradasi bahan organik, meningkatkan produksi dan kualitas biogas, dan menurunkan waktu retensi [5]

\section{Metodologi Penelitian}

Metode penelitian yang diuraikan dibawah ini mencakup bahan, aklimatisasi, rancangan digester, serta pengoperasian digester.

\section{Bahan}

Air buangan domestik yang digunakan dalam penelitian berasal dari influent IPAL Cemara, Medan.

\begin{abstract}
Aklimatisasi
Sumber inokulum yang digunakan pada penelitian ini yaitu kotoran sapi yang terdiri dari kultur campuran [11]. Proses aklimatisasi inokulum untuk masing-masing tahap asidogenesis dan metanogesis dilakukan pada skala laboratorium. Kotoran sapi segar dicampur dengan aquades dengan perbandingan 1:1 (v/v) kemudian disaring untuk memisahkan padatan yang ada dikotoran sapi tersebut. Kotoran sapi yang telah disaring dicampur dengan air buangan domestik dengan perbandingan 1:1 (v/v) kemudian dikondisikan pada suasana asam, yaitu pH 5.5 menggunakan $\mathrm{H}_{3} \mathrm{PO}_{4}$ untuk tahap asidogenesis dan $\mathrm{pH}$ netral $(\mathrm{pH} 7)$. Campuran inokulum tersebut dimasukkan kedalam digester, dialirkan gas nitrogen selama \pm 10 menit kedalam digester, ditutup rapat.dan diinkubasi pada suhu ruang. Lama proses aklimatisasi berlangsung selama 10 hari hingga terbetuk biogas [7].
\end{abstract}

\section{Rancangan Digester}

Rancangan digester anaerobik satu tahap dan dua tahap yang digunakan dalam penelitian ini ditunjukkan pada Gambar 1. Digester terbuat dari bahan plastik dengan volume efektif $7 \mathrm{~L}$ dan dilengkapi dengan water displacement dan keran outlet.

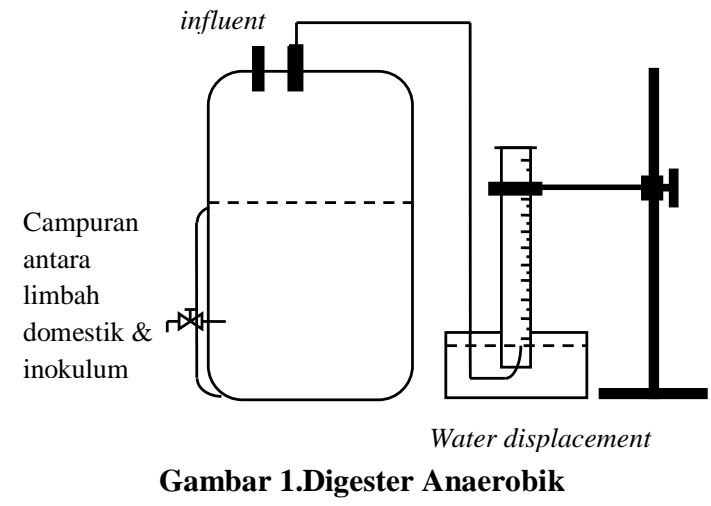

\section{Pengoperasian Digester}

a. Pengoperasian Digester Satu Tahap (R1)

Bahan baku yang digunakan pada tahap ini adalah kotoran sapi (1 liter) yang telah diaklimatisasi kondisi netral dicampur hingga homogen dengan air buangan domestik (6 liter) lalu dikondisikan pada $\mathrm{pH} 7$ kemudian dimasukkan ke dalam digester satu tahap. 
Sebelum ditutup rapat, dialirkan gas nitrogen selama \pm 10 menit kedalam digester.

b. Pengoperasian Digester Dua Tahap (R2)

Bahan baku yang digunakan pada tahap ini adalah kotoran sapi (1 liter) yang telah diaklimatisasi kondisi asam dicampur hingga homogen dengan air buangan domestik (6 liter) lalu ditambahkan $\mathrm{H}_{3} \mathrm{PO}_{4}$ hingga diperoleh $\mathrm{pH}$ campuran $\mathrm{pH}$ 5.5. Kemudian dimasukkan ke dalam digester dua tahap (R21). Sebelum ditutup rapat, dialirkan gas nitrogen selama \pm 10 menit kedalam digester. Setelah 2 hari, campuran dari R2-1 dinetralkan dengan penambahan $\mathrm{NaOH}(\mathrm{pH}$ 7) kemudian ditambahkan inokulum yang teraklimatisasi $\mathrm{pH}$ netral (1 liter) sebelum dimasukkan kedalam digester. Gas nitrogen juga dialirkan selama \pm 10 menit kedalam digester kemudian ditutup rapat.

Pengukuran $\mathrm{pH}$ dilakukan dengan menggunakan $\mathrm{pH}$ meter. Analisa COD dilakukan dengan metode titimetri berdasarkan SNI 066989.22 tahun 2004. Pertumbuhan bakteri diamati dengan cara mengukur nilai VSS pada sampel dengan metode gravimetric (Standard Methods 2540 E, 1997). Metode yang digunakan dalam analisa VFA adalah destilasi uap (steam destilation) (Polish Normalized Committee Methods PN-75/C-04616). Pengukuran biogas dilakukan dengan menggunakan metode Water Displacement yaitu dengan cara mengamati volume air yang berkurang pada gelas ukur terbalik pada rangkaian water displacement. Jumlah air yang keluar dari gelas ukur tersebut diukur volumenya dengan asumsi bahwa volume air yang keluar sama dengan volume biogas.

\section{Hasil dan Pembahasan}

Hasil pengamatan selama proses pengolahan anaerobik ditampilkan dengan melihat karakteristik air buangan domestik, karakteristik inokulum, karakteristik bahan campuran, $\mathrm{pH}$ dan konsentrasi VFA, penyisihan bahan organik, aktivitas bakteri dalam sistem, dan produksi biogas.

\section{Karakteristik Air Buangan Domestik}

Pada bagian ini akan dikaji tentang karakteristik air buangan domestik yang digunakan sebagai substrat. Air buangan domestik yang digunakan adalah influent IPAL Cemara dengan karakteristik seperti ditampilkan pada Tabel 1 .
Tabel 1. Karateristik Influent IPAL Cemara, Medan

\begin{tabular}{|l|c|c|}
\hline Parameter & Satuan & Nilai \\
\hline $\mathrm{pH}$ & & 6.9 \\
\hline $\mathrm{COD}$ & $\mathrm{mg} / \mathrm{L}$ & 505.44 \\
\hline TSS & $\mathrm{mg} / \mathrm{L}$ & 240.15 \\
\hline
\end{tabular}

Tabel 1 menunjukkan bahwa air buangan domestik yang akan diolah mempunyai kandungan organic yang rendah jika dibandingkan dengan air limbah yang berasal dari sumber lain seperti industri, peternakan dan lain-lain. Akan tetapi, sebagian besar senyawa organik kompleks ditemukan pada air buangan domestik, seperti karbohidrat, fat, minyak dan lemak, protein, dan sebagainya. Hal ini menunjukkan bahwa karakteristik air buangan domestik merupakan yang paling kompleks dibandingkan dengan air buangan yang berasal dari industri, komersial, pertanian [3].

Pengolahan anaerobik melibatkan senyawa organik kompleks dimana bahan-bahan organik terdegradasi secara beruntun oleh berbagai jenis mikroorganisme. Berdasarkan hal ini, pengolahan anaerobik mempunyai potensi untuk mengolah low-strength wastewater seperti air buangan domestik [12].

\section{Karakteristik Inokulum}

Hasil penelitian mengenai karakteristik inokulum yang telah teraklimatisasi dapat dilihat pada Tabel 2 berikut.

Tabel 2. Karakteristik Inokulum Kotoran Sapi

\begin{tabular}{|l|c|c|c|}
\hline \multirow{2}{*}{ Parameter } & \multirow{2}{*}{ Satuan } & \multicolumn{2}{|c|}{ Teraklimatisasi } \\
\cline { 3 - 4 } & & $\begin{array}{c}\text { Asam } \\
\text { (pH 5.5) }\end{array}$ & $\begin{array}{c}\text { Netral } \\
\text { (pH7) }\end{array}$ \\
\hline TSS & $\mathrm{mg} / \mathrm{L}$ & 5625.15 & 4866.02 \\
\hline VSS & $\mathrm{mg} / \mathrm{L}$ & 4212.86 & 3712.78 \\
\hline
\end{tabular}

Berdasarkan Tabel 2, kuantitas mikroba yang telah teraklimatisasi baik pada kondisi asam dan netral yang dipantau melalui konsentrasi VSS berturut-turut yaitu $4212.86 \mathrm{mg} / \mathrm{L}$ dan 3712.78 $\mathrm{mg} / \mathrm{L}$. Nilai tersebut telah melampaui batas minimal yang disarankan oleh peneliti terdahulu sebesar $3000 \mathrm{mg} / \mathrm{L}$ sehingga dapat dikatakan bahwa mikroba telah siap sebagai agen pendegradasi. Besarnya kuantitas biomassa mikroba tersebut dapat meningkatkan proses penguraian bahan organik [9].

\section{Karakteristik Bahan Campuran}

Adapun karakteristik substrat yang dicampurkan dengan inokulum (bahan campuran) pada saat awal pengoperasian digester ditunjukkan dalam Tabel 3. 
Tabel 3. Karakteristik Bahan Campuran

\begin{tabular}{|l|c|c|c|c|}
\hline \multirow{2}{*}{ Parameter } & \multirow{2}{*}{ Satuan } & \multirow{2}{*}{ R1 } & \multicolumn{2}{|c|}{ R2 } \\
\cline { 3 - 5 } & & & R2-1 & R2-2 \\
\hline $\mathrm{pH}$ & & 7.1 & 5.5 & 7.1 \\
\hline $\mathrm{COD}$ & $\mathrm{mg} / \mathrm{L}$ & 705.12 & 755.04 & 617.6 \\
\hline $\mathrm{VSS}$ & $\mathrm{mg} / \mathrm{L}$ & 542.15 & 603.31 & 1203.34 \\
\hline VFA & $\mathrm{mg} / \mathrm{L}$ & 20 & 20 & 160 \\
\hline
\end{tabular}

Keterangan:

R1 : Digester anerob satu tahap

R2 : Digester anaerob dua tahap

R2-1 : Digester anaerob dua tahap:tahap pertama

R2-2 : Digester anaerob dua tahap:tahap kedua

Berdasarkan Tabel 3 karakteristik bahan campuran diperoleh nilai $\mathrm{pH}$ awal pada $\mathrm{R} 1$ dan R2 berbeda masing-masing yaitu 7.1 dan 5.5. Adapun pada R1 diatur pada kondisi $\mathrm{pH}$ netral sementara pada R2-1 dijalankan selama 2 hari pada kondisi optimum proses asidifikasi yaitu kondisi asam ( $\mathrm{pH}$ 5.5) dengan penambahan asam fosfat $\left(\mathrm{H}_{3} \mathrm{PO}_{4}\right)$.

Setelah melewati R2-1, R2-2 dijalankan selama 38 hari pada kondisi optimum proses metanogenesis yaitu kondisi netral ( $\mathrm{pH}$ 7) dengan penambahan $\mathrm{NaOH}$. Netralisasi output R2-1 yang bersifat asam dilakukan dengan penambahan $\mathrm{NaOH}$.

Sementara untuk parameter lain seperti COD, VSS dan VFA pada R1 dan R2-1 dapat dilihat bahwa nilai pada kondisi awal masing-masing digester tidak menunjukkan perbedaan yang signifikan. Pada R2-2 menunjukkan nilai COD, VSS dan VFA yang berbeda sebab nilai input pada R2-2 merupakan hasil ouput dari R2-1 dengan penambahan inokulum sebelum dimasukkan kedalam digester [5].

\section{pH dan Konsentrasi VFA}

$\mathrm{pH}$ adalah parameter penting dalam proses anaerobik yang dapat digunakan untuk mengendalikan metabolisme (VFA) sekaligus memilih mikroorganisme yang paling mampu bertahan [9]. Pengamatan parameter $\mathrm{pH}$ dan VFA ditunjukkan pada Gambar 2.

Gambar 2 menunjukkan bahwa selama 40 hari nilai $\mathrm{pH}$ berada dalam kondisi optimum yang diharapkan yaitu kondisi netral pada R1, R2-1 dan R2-2. Hal ini bisa saja terjadi karena $\mathrm{pH}$ campuran diatur sebelum dimasukkan kedalam digester. Setelah melewati proses asidifikasi (R2-1) selama dua hari, campuran dikeluarkan dan dilakukan pengaturan $\mathrm{pH}$ dengan penambahan $\mathrm{NaOH}$. Adapun Ion $\mathrm{Na}^{\prime}$ dapat bersifat sebagai penyangga terhadap asam asetat yang dihasilkan dari proses biodegradasi substrat membentuk natrium asetat sehingga $\mathrm{pH}$ sistem dapat dijaga sekitar 7 [14].

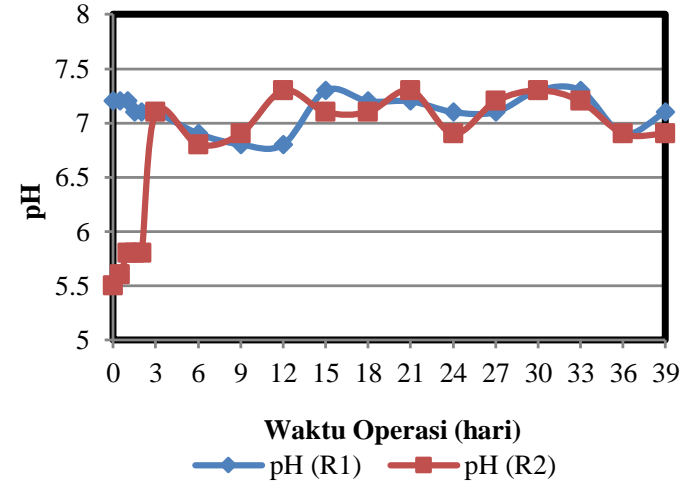

\section{Gambar 2. Profil Pengamatan Parameter pH pada Digester Anaerobik Satu Tahap dan Dua Tahap}

Berdasarkan hasil percobaan yang telah dilakukan sebelumnya, interval $\mathrm{pH}$ pada fase hidrolisis-asidogenesis yaitu $5.8 \quad-6.13$ sementara rentang $\mathrm{pH}$ yang dimati pada fase asetogenesis-metanogenesis yaitu $7.68-8.03$ [15].

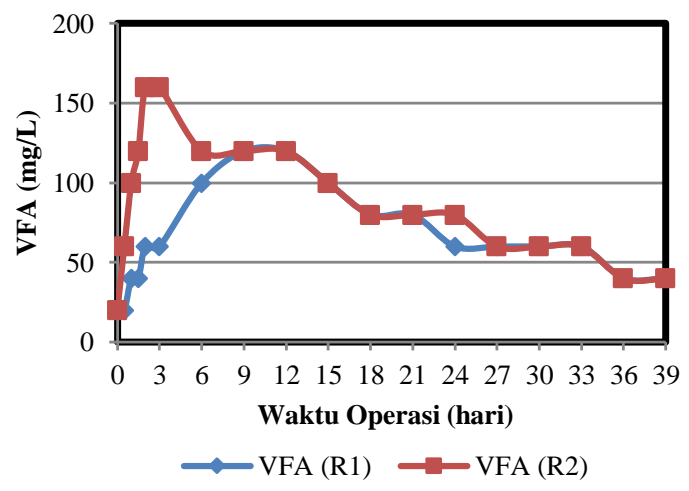

Gambar 3. Profil Pengamatan Parameter VFA pada Digester Anaerobik Satu Tahap dan Dua Tahap

Sementara itu, pada Gambar 3 dapat dilihat nilai VFA mengalami fluktuasi. Proses asidifikasi yang terjadi pada awal pengolahan anaerobik dapat meningkatkan biokonversi organik kompleks. Terurainya bahan organik ini tampak dari meningkatnya parameter VFA.

Kemudian nilai VFA mengalami penurunan secara berangsur-angsur hingga hari terakhir pengamatan sebab VFA yang terbentuk akan diurai menjadi gas metan $\left(\mathrm{CH}_{4}\right)$ dan kabon dioksida $\left(\mathrm{CO}_{2}\right)$ oleh bakteri metanogenik [5].

Adapun konsentrasi VFA maksimal yaitu $160 \mathrm{mg} / \mathrm{L}$ pada hari kedua pada R2-1 dan 120 mg/L pada hari ke-9 pada R1. Peningkatan nilai VFA yang lebih cepat dan signifikan yaitu selama dua hari pada R2-1 dibandingkan nilai 
VFA pada R1 disebabkan oleh kondisi asam mendukung pertumbuhan bakteri asidogenik sehingga nilai VFA yang diperoleh bertambah seiring dengan laju pendegradasian subtrat.

\section{Penyisihan Bahan Organik}

COD melambangkan keberadaan senyawa organik dalam suatu bahan. Penyisihan bahan organik ditunjukkan pada Gambar 4.

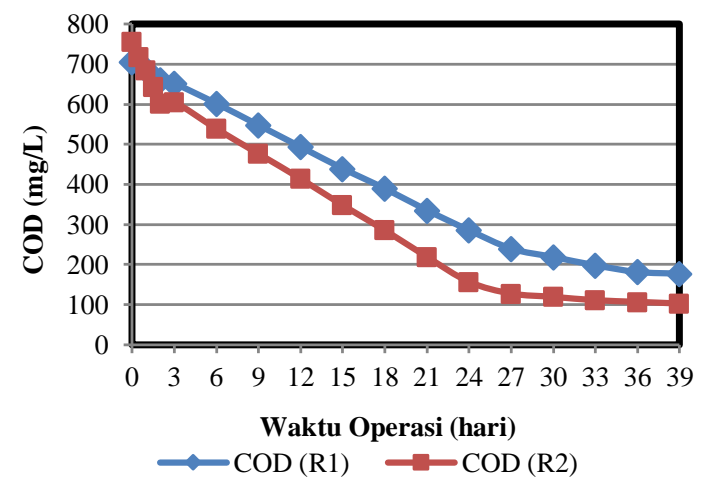

\section{Gambar 4. Profil Pengamatan Parameter COD pada Digester Anaerobik Satu Tahap dan Dua Tahap}

Gambar diatas menunjukkan bahwa penyisihan bahan organik selama 40 hari pada R1 dan R2 cenderung memiliki pola yang sama, yaitu mengalami penurunan secara bertahap. Penyisihan tertinggi diperoleh oleh R2 yaitu sebesar $653.12 \mathrm{mg} / \mathrm{L}$. Hal ini dapat dimengerti karena penyisihan COD pada tahap asidifikasi (R2-1) dan penambahan inokulum pada (R2-2) membantu penyisihan COD yang lebih cepat pada R2 yang dapat dilihat pada Gambar 4 bahwa nilai COD mulai stabil pada hari ke-30 dibandingkan nilai COD pada R1.

Penurunan nilai COD ini disebabkan oleh terjadinya perombakan bahan-bahan organik oleh mikroorganisme yang beraktivitas dalam digester anaerobik. Pada proses perombakan bahan organik tersebut mikroba menggunakan bahan organik sebagai sumber makanan [13]. Sehingga pada akhir proses fermentasi anaerobik baik pada R1 dan R2 kandungan bahan organik semakin sedikit sehingga menurunkan nilai COD. Presentase efisensi penyisihan COD pada R1 dan R2 berturut-turut yaitu $74.32 \%$ dan $85.1 \%$.

\section{Aktivitas Bakteri Anaerobik Dalam Sistem \\ Konsentrasi volatile suspended solid (VSS) yang diamati pada penelitian ini tidak diamati sebagai parameter air limbah tetapi sebagai parameter yang menunjukkan pertumbuhan}

mikroba [1]. Aktivitas bakteri anaerobik dapat dilihat pada gambar berikut

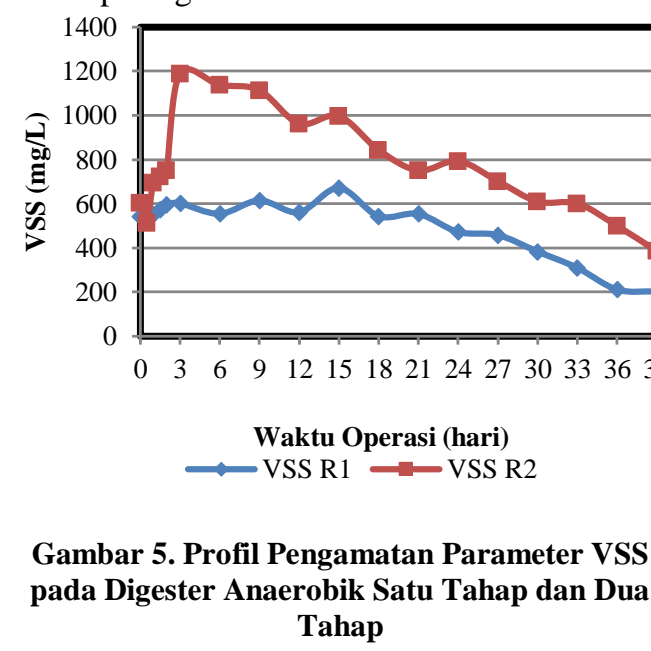

Gambar 5 menunjukkan bahwa konsentrasi bakteri mempunyai kecenderungan meningkat. Hal ini menarik untuk ditinjau karena peningkatan konsentrasi biomassa berkaitan dengan waktu kontak antara bakteri dan air buangan akan menghasilkan pertumbuhan mikroba [2]. Proses asidifikasi yang terjadi pada R2-1 diketahui sebagai pertumbuhan bakteri hidrolitik-asidogenik dimana pertumbuhan bakteri pada tahap ini berlangsung lebih cepat dibandingkan bakteri metanogenik. Hal ini dapat dilihat bahwa dalam waktu 48 jam, nilai VSS pada R2-1 mencapai $750.06 \mathrm{mg} / \mathrm{L}$ yang berarti kondisi asam pada R2-1 mendukung laju pertumbuhan mikroba asidogenik. Akan tetapi peningkatan yang signifikan yang terjadi pada hari ketiga pada R2-2 disebabkan oleh penambahan inokulum setelah R2-1.

Setelah megalami peningkatan, baik pada R1 maupun R2, konsentrasi VSS mengalami penurunan secara terus-menerus hingga hari terakhir pengamatan terlebih pada R2. Penurunan nilai VSS ini dapat disebabkan oleh kondisi lingkungan seperti kekurangan substrat, produksi zat beracun (toxic product) dan growth limiting nutrient yang tidak mendukung untuk pertumbuhan mikroba [6].

\section{Produksi Biogas}

Tahap metanogenesis merupakan tahap paling akhir dalam pembentukan biogas. Pada tahap ini, bakteri metanogenik atau bakteri pembentuk metan menghasilkan gas metan $\left(\mathrm{CH}_{4}\right)$, karbondioksida $\left(\mathrm{CO}_{2}\right)$, dan sedikit gas lain (seperti $\mathrm{H}_{2} \mathrm{~S}$ ) [8]. Laju produksi biogas ditunjukkan pada Gambar 6.

Gambar 6 menunjukkan produksi biogas yang mengalami fluktuatif selama 40 hari. Secara umum produksi biogas baik pada R1 dan 
R2 yaitu lambat pada saat awal dan akhir dari pengamatan. Volume biogas yang lambat pada saat awal disebabkan oleh waktu generasi bakteri metanogenik yang lambat sehingga pengubahan produk VFA menjadi biogas cenderung lambat dan volume biogas yang dihasilkan semakin sedikit pada akhir pengamatan ini disebabkan semakin berkurangnya substrat dalam digester.

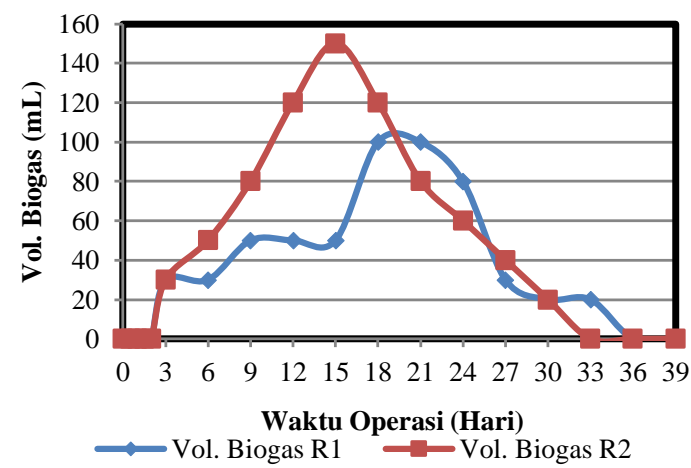

Gambar 6. Profil Pengamatan Laju Produksi Biogas pada Digester Anaerobik Satu Tahap dan Dua Tahap.

Adapun volume kumulatif biogas yang dihasilkan pada R1 dan R2 berturut-turut yaitu $560 \mathrm{~mL}$ dan $750 \mathrm{~mL}$ sementara yield biogas yang didapat pada R1 dan R2 masing-masing yaitu $0.15 \mathrm{~L} / \mathrm{g} \mathrm{COD}_{\text {terkonversi }}$ dan $0.16 \mathrm{~L} / \mathrm{g} \mathrm{COD}_{\text {terkonversi }}$. Pada penelitian sebelumnya, pengolahan air buangan domestik satu tahap didapatkan yield biogas tertinggi sebesar $0.10 \mathrm{~L} / \mathrm{g} \mathrm{COD}_{\text {terkonversi }}$ [12].

\section{Kesimpulan}

Terdapat pengaruh pengolahan anaerobik satu tahap dan dua tahap terhadap kinerja reaktor dalam pengolahan air buangan domestik dilihat dari segi laju degradasi substrat (COD), laju pertumbuhan mikroorganisme (VSS) dan laju produksi metabolit (VFA) dan laju produksi biogas. Konsentrasi VFA tertinggi yaitu pada hari kedua pada digester anaerobik dua tahap. Efisiensi penyisihan COD ada digester anaerobik satu tahap dan dua tahap berturut-turut adalah $74.32 \%$ dan $85.1 \%$. Konsentrasi biomassa pada digester dua tahap lebih tinggi dibandingkan digester anaerobik satu tahap disebabkan adanya penambahan inokulum setelah dua hari. Laju produksi biogas bersifat fluktuatif pada digester anaerobik satu tahap dan dua tahap dengan volume akumulatif berturut-turut yaitu $560 \mathrm{~mL}$ dan $650 \mathrm{~mL}$.

\section{Daftar Pustaka}

A1] A.C. Nopharatana, W. P.
Pullammanappallil and Clarke, Kinetics and Dynamic Modeling Of Batch Anaerobic Digestion Of Municipal Solid Waste in a Stirred Reactor, Waste Management, 27, 2007, 595-603.

[2] A. Schnurer and A. Jarvis, Microbiological Handbook for Biogas Plants, Swedish Gas Centre Report 207, 2010, p. 7.

[3] D.H.F. Liu and B.G. Liptak, Wastewater Treatment, Lewis Publishers, Boca Raton, 2000, p. 219.

[4] F.G. Pohland and S. Ghosh, Developments in Anaerobic Stabilization of Organic Wastes, the Two-Phase Concept, Enviromental. Technologies, 1, (1971) 255-266.

[5] G.N.Demirer, and S. Chen, Two-Phase Anaerobic Digestion of Unscreened Dairy Manure, Process Biochemistry, 40, (2005) 3542-3549.

[6] I. Wauton dan R.H. Gumus, Effect of BioAugmentation on Biokenetic Parameters in the Mesophilic Anaerobic Digestion of Poultry Droppings, International Journal of Engineering Research and Development, 6, (2013) $25-30$

[7] Iriani dkk, Fermentasi Anaerobik Biogas Dua Tahap dengan Aklimatisasi dan Pengkondisian $\mathrm{pH}$ Fermentasi, Jurnal Teknik Kimia dan Lingkungan, 1, (2017) 110.

[8] M.C.Jr. Sterling et al, Effects of Ammonia Nitrogen on $\mathrm{H} 2$ and $\mathrm{CH} 4$ production During Anaerobic Digestion of Dairy Cattle Manure, Bioresource Technologies, .77, (2001) 9-18.

[9] M.F. Temudo, G.Muyzer, R. Kleerebezem and M. Van Loosdrecht, Diversity of Microbial Communities in Open Mixed Culture Fermentations: Impact of the $\mathrm{pH}$ and Carbon Source, Biotechnology and Bioengineering, 80, (2008) 1121-1130.

[10] M.H. Gerardi, The Microbiology of Anaerobic Digesters, John Wiley \& Sons, Inc, 2003, p. 51-57.

[11] P.M. Christy, L.R.Gopinath and D. Divya, Microbial Dynamics During Anaerobic Digestion of Cow Dung, International Journal of Plant, Animal and Enviromental Sciences, 4, (2014) 86-94.

[12] R. Cheerawit et al, Biogas Production from Co-Digestion of Domestic Wastewater and Food Waste, Health and The Environment Journal, 3, (2012) 1 - 9

[13] S. Pranshanth, P. Kumar and I. Mehrotra, Anaerobic Degradability: Effect of Particulate COD, Journal of Enviromental Engineering, 132, (2006) 488 - 496. 
[14] V.Blonskaja, A. Menert, R. Vilu, Use of Two-Stage Anaerobic Treatment for Distillery Waste, Advances in Enviromental Research, 7, (2003) 671678.

[15] Y.G. Puebla et al, Effect of the Recycle on the Two Phase Anaerobic Digestion Processs Treating Coffee Wet Wastewater, 2014, $1-4$. 